\title{
CAN BRAND IMAGE BE RECOVERED AFTER NEGATIVE PUBLICITY? EFFECTS OF SEVERITY AND CORPORATE SOCIAL RESPONSIBILITY
}

\author{
DOI: 10.17261/Pressacademia.2019.1175
}

JMML- V.6-ISS.4-2019(4)-p.239-251

May-Ching Ding ${ }^{1}$, Chih-Huang Lin ${ }^{2}$, Yu-Bing Wang ${ }^{3}$, Yi-Jing Lee ${ }^{4}$

${ }^{1}$ Feng Chia University, College of Business, 100 Wenhwa Rd, Seatwen, Taichung, 40724, Taiwan ROC. mcding@fcuoa.fcu.edu.tw, ORCID: 0000-0002-0888-9890

${ }^{2}$ Feng Chia University, College of Business, 100 Wenhwa Rd, Seatwen, Taichung 40724, Taiwan ROC. linchihh@fcuoa.fcu.edu.tw,ORCID: 0000-0002-4813-154X

${ }^{3}$ Feng Chia University, College of Business, 100 Wenhwa Rd, Seatwen, Taichung, 40724, Taiwan ROC. ybwang@mail.fcu.edu.tw ORCID: 0000-0002-4379-3595

${ }^{4}$ Feng Chia University, College of Business, 100 Wenhwa Rd, Seatwen, Taichung 40724, Taiwan ROC. lee.yj@m2k.com.tw,ORCID:0000-000209439-7949

Date Received: November 2, 2019

Date Accepted: December 24, 2019

To cite this document

Ding, M.C., Lin, C.H., Wang, Y.B. \& Lee, Y.J. (2019). Can brand image be recovered after negative publicity? Effects of severity and corporate social responsibility. Journal of Management, Marketing and Logistics (JMML), V.6(4), p.239-251.

Permemant link to this document: $\underline{\text { http://doi.org/10.17261/Pressacademia.2019.1175 }}$

Copyright: Published by PressAcademia and limited licenced re-use rights only.

\begin{abstract}
Purpose- This research examines the effectiveness of CSR's function to minimize and repair the severity of negative publicity towards company's brand image in two periods of time.

Methodology- A convenient student sampling of 225 respondents was used and employed ANOVA and T-test to measure the significance difference of brand image recovery between Time 0 (the time when the negative publicity incident occurred) and Time1 (a year after).

Findings- Findings showed that brand image was higher (recovered) in Time 1 than in Time 0 whether factoring in CSR or not. In addition, CSR can still positively redeem brand image from negative publicity in Time 0 compared to Time 1.

Conclusion- Findings supported that CSR can function and serve as a corporate image 'safety net'. The implication of this study recommends that companies should invest in one or more domains of CSR initiates, such as employee training or social and community involvements in case of negative publicity events.
\end{abstract}

Keywords: Negative publicity, CSR, severity, time, brand image recovery.

JEL Codes: M30, M31, M37

\section{INTRODUCTION}

Food safety issues have been a series of major episodes since 2011. Such scandals have widespread effect over the country. News and media have elevated the negative publicity and spread public fears over months. In one hand, consumers have lost faith and trust in particular some well-known and history old brand name companies. On the other hand, unethical businesses have struggled to find a way to handle negative publicity in order to rebuild their reputation (brand image and trust).

The most recent food safety scandals have happened in soft drinks, edible oils, and dried tofu products. Back to 2011, News reported that soft drinks contained industrial plasticizer, an agent that can harm children's health (major consumers consumed soft drinks daily sometimes). Following the revelation, another severe publicity has been the edible oil happened in early 2013 and the episode has been a going concern from the public. News started from Chang Chi Foodstuff Factory that the company has been selling adulterated oil products. Their oil products had mixed olive oil with cheaper cottonseed variety to lower production costs and to make the oil look purer by adding coloring agent, copper chlorophyll in since 2006 (Chung, 2013). The worst thing is that Chang Chi Company was also a manufacturer (OEM) for several leading and oldest food companies in Taiwan. Consequently, the entire food industry has been under the fire of the scandal. 
In late 2014, News reported similar scandals happened in the dried tofu products. The products have many flavored types that found to be contaminated with toxic industrial dye methyl yellow which had been used for at least 20 years and few days later the regular tofu products were also adulterated with carcinogens (Hsu, 2014). The origin manufacturer, Chien-Hsin Enterprises located in southern Tainan city, was also the supplier to 44 manufacturers for the dried tofu products (Hsu, 2014). As a result, negative publicity of such food scandals has not only damaged company reputation (brand image and trust) and consumer trust. At the same time, if the food industry wants to survive they have to strive to rebuild its reputation soon.

Due to these chemicals that can severely damage people's liver and cause cirrhosis if excessive consumption of the agents, consumers have lost their faith (trust) and skeptical about brand name companies. According to one report, 80\% of Taiwan's consumers are concerned about food safety problem (Wu and Kao, 2013) and they have expressed their outrage. As a result, over 3,000 consumers have taken actions by jointly filed a class-action lawsuit over the adulterated food companies and the Consumer Protection Commission would file the lawsuit on their behalf (Chung, 2013). Many public boycotts have targeted at those irresponsible corporations. Recently, the News has reported that public boycotts have resurged against the big food conglomerates whose president was sentenced for the eatable oil scandal. In future, food safety issues incurred by brand companies are likely to happen and continuous public concerns are believed to get stronger in Taiwan.

Scholars have spoken out loud and pointed out it is time to take a look in business ethics and social responsibility. Scholars have started taking corporate social responsibility (CSR) as a strategic (marketing) approach for sustainability based on doing the right things that not only can provide a unique competitive advantage to firms but also social benefits at large (Elkington, 1994; Porter \& Kramer, 2006; Rodriguez et al., 2002; Smallbone, 2004). CSR functions as a key component of a firm's marketing communications by delivering values that meet consumers' expectations resulted in improving corporate performance and reputation, while helping worthy causes at the same time (Bakar and Ameer, 2011; Charter et al., 2002; Nan and Heo, 2007; Sen and Bhattacharya, 2001). A good corporate reputation that is affected by the CSR initiatives will bring brand value and trust to the corporation (Perrini et al., 2010), specifically through consumers' positive attitudes toward the brand and enhanced perceptions of credibility toward the CSR initiatives (Becker-Olsen and Hill, 2006; Lachowetz et al., 2002). Consequently, scholars have suggested that CSR can be an effective communication tool to offer a shelter or restore corporate reputation and image (brand image and trust) after the negative publicity (Benoit, 1997; Klein and Dawar, 2004; Vanhamme and Grobben, 2009). However, literature in this arena (CSR as a way to counter negative publicity) is scarce (Vanhamme and Grobben, 2009) and needs further investigation.

Seemingly, CSR has a tendency and ability to reduce consequences of service failure and negative publicity (Joireman, Smith, Liu, and Arthurs, 2015). Benefits derived from a long-term marketing investment can be damaged severely over night by an incident of negative publicity. In other word, a well-known corporate brand image can be tarnished hastily by negative publicity (Cho, 2005; Henthorne and Henthorne, 1994; Zhu and Chang, 2013).

Literature gaps in CSR and negative publicity signify several issues that are needed for further investigations. First, most previous researches have limited to case studies and few consider the more realistic scenarios (Xie and Peng, 2010). Second, limited research has explored severity of negative publicity on corporate brand and consumer responses (Brady et al., 2008) and duration (how long) of consumer reaction to negative publicity (Henthorne and Henthorne, 1994; de Matos and Veiga, 2005). Third, scholars have recommended that CSR can offset the impact of negative publicity (Vanhamme and Grobben, 2009; Zhu and Chang, 2013) but researches of CSR under what kind of conditions that are likely to mitigate negative publicity are either missing or scarce (Berens, van Riel, and van Rekom, 2007). This research tries to fulfill the literature gaps in the field of negative publicity.

In practice, it is often difficult for companies to provide a product or service with zero defects (i.e. service failures or negative publicity). Scholars have suggested that CSR can be an effective communication tool to offer a shelter or restore corporate reputation (brand image and trust) after the negative publicity (Benoit, 1997; Klein and Dawar, 2004). If companies cannot completely eliminate the product or service failure that incurs negative publicity, then understanding how CSR activities can be of considerable value in improving the effect of negative events is crucial (Schoefer and Ennew 2005). Leveraging this thought, if a product or service failure (in particular due to social irresponsibility) becomes a negative publicity and then how CSR initiatives can or cannot rectify the event and regain brand image will be an intriguing research topic.

This study applies a real scenario to explore how different severity of negative publicity and leveraging CSR to recover brand image in different times (negative publicity incurred, Time 0 and a year after the negative publicity, Time 1 ). Thus, the purpose of the study is as follow:

1. How different the level of severity of negative publicity impacts differently on corporate brand image in Time 0. 
2. How different a corporate history of CSR efforts can mitigate the impact differently on brand image after negative publicity in Time 0.

3. How different interactions between the severity of negative publicity and the history of CSR efforts impact differently on brand image in Time 0 .

4. A year after, Time1, the three purposes mentioned above will be re-examined to compare the differences (changes) on brand images between Time 1 and Time 0 .

\section{LITERATURE REVIEW AND RESEARCH HYPOTHESES}

\subsection{Negative Publicity}

Impression formation literature in social psychology has provided a theoretical foundation to explain how people deal with positive and negative information (Cho, 2005; Fiske, 1980; deMatos and Veiga, 2005). In the stream of public relation literature, researchers in particular have investigated effects of negative publicity on corporate performance (Henard, 2002; Xie and Peng, 2010). Definition for negative publicity from the two research field is somehow similar and refers to potential damaging information regarding a product, service, corporation, or individuals in the form of news in prints and televsions, broadcasting, word of mouth, and other kinds of media (Reidenback et al., 1987; Sherell and Reidenbach, 1986).

Marketing researchers have recently shown interests and investigated the role of negativity effect based on the impression formation theory on consumers' psychological attitude and behavioral reactions toward corporate publicity (Ahluwalia et al., 2000; Cho, 2005; Griffin et al., 1991; Pullig et al., 2006; Vanhamme and Grobben, 2009; Xie and Peng, 2010; Zhu and Chang, 2013). Publicity in particular the negative one is one of the major information decoded by consumers to update their associations with a corporate brand (Xie and Peng, 2010). Further, recent studies have found that the effects of negative publicity on one brand can affect other brands (Dahlen and Lange, 2006), brand attitude (Li, 2015), brand evaluation (Cho, 2005), corporate image (Zhu and Chang, 2013), and consumer attitudes and intentions (Griffin et al., 1991). Scholars also have explored the effects of moderators such as consumer commitment (Ahluwalia et al., 2000), corporate advertising (Cho, 2005), and consumer involvement (de Matos and Veiga, 2005).

Literature gap in negative publicity signifies several issues that needed for further investigation. First, most previous research has limited to case studies and few studies consider the more realistic scenarios (Xie and Peng, 2010). Second, limited research has explored severity of negative publicity on corporate brand and consumer responses (Brady et al., 2008) and duration (how long) of consumer reaction to negative publicity (Henthorne and Henthorne, 1994; de Matos and Veiga, 2005). Last, scholars have recommended that CSR can offset the impact of negative publicity (Vanhamme and Grobben, 2009; Zhu and Chang, 2013).

\subsection{The Sustainability of CSR Initiatives}

The concept and definition of CSR have as yet no real consensus among scholars. The most prevailing CSR definition was probably Carroll's pyramid model, based on the economic on the bottom and followed by legal responsibilities to ethical and philanthropic responsibilities on the top (Carroll, 1979, 1991, 1996). Recent development has converged the economic, social, and environmental responsibilities to create a strategic approach by creating societal value that also fosters corporate sustainability (Dyllick and Hockerts, 2002; Marrewijk, 2003; Porter and Kramer, 2011). For sustainable marketing, such unmet social needs provide market opportunities for companies to differentiate and reposition themselves to gain competitive advantage and economic success by fulfilling carefully defined unmet societal needs and at the same time benefiting society (Charter et al., 2002).

CSR consists of social actions performed by corporations for the purpose of fulfilling social needs (Angelidis and Ibrahim, 1993). It also involves a corporation's willingness to go beyond its legal obligations to set up its policies and practices that are socially involved for the benefit of the society (Enderle and Tavis, 1998). In addition, Lerner and Fryxell (1988) state that a firm's CSR actions should be in harmony with societal values and expectations, and Marrewijk (2003) further defines CSR by integrating economic, social, and environmental responsibilities in relation to the ultimate goal of corporate sustainability, meeting the present needs without scarifying future generation's needs.

Further, Mohr et al. (2001) separate CSR into two general classifications. The first classification discusses CSR and the various stakeholders of the organization (e.g. owners, customers, employees, and the community). The second category is based on Kotler's (2008) societal marketing concept. These two definitions emphasize that a socially responsible company should have concerns beyond just short-term profitability. The concept of CSR also has been defined to suggest that companies integrate social 
and environmental concerns into their business operations and their interactions with their stakeholders on a voluntary basis (Commission of the European Communities, 2001).

Consumer CSR is defined as the commitment of a company to respect consumer rights and interests (Perrini et al., 2010). Consumers, like any stakeholder group, will primarily observe a firm's behavior toward them. When focusing on consumers, socially responsible firms should be capable of developing a distinctive market image to both attract and retain customers. Therefore, if a company can protect consumers' rights or carefully check the origin of products it sells, we could say this company has consumer CSR. Environmental CSR can be defined as the commitment by a company to respect and protect the natural environment (Perrini et al., 2010). A company that is environmentally responsible will try to prevent pollution, reduce environmental damage that their products may cause and in general be sustainable and bring brand value to the company (First and Khetriwal, 2010; Hart, 1995).

There are many ways of implementing CSR initiatives in marketing; nonetheless, the philanthropic type of CSR seems to be the most effective in enhancing corporate reputation through the association of brand/cause (Polonsky and Speed, 2001). As a form of altruistic CSR, the perception of 'giving' might also lower consumers' skepticism toward the firm's intentions, thereby increasing the positive attitude and behavioral intentions toward CSR initiatives (Baghi et al., 2009; Webb and Mohr, 1998) and the brand image (Vanhamme and Grobben, 2009). A good corporate reputation that is affected by the CSR initiatives will bring brand value and trust to the corporation (Perrini et al., 2010), specifically through consumers' positive attitudes toward the brand and enhanced perceptions of credibility toward the CSR initiatives (Becker-Olsen and Hill, 2006; Lachowetz et al., 2002).

Consequently, scholars have suggested that CSR can be an effective communication tool to offer a shelter or restore corporate reputation and image (brand image and trust) after the negative publicity (Benoit, 1997; Klein and Dawar, 2004; Vanhamme and Grobben, 2009). However, literatures in this arena of CSR as a way to counter negative publicity (Vanhamme and GRobben, 2009) and researches of CSR under what kind of conditions that are likely to mitigate negative publicity are scarce (Berens, van Riel, and van Rekom, 2007) and thus need further investigation.

\subsection{Brand Image}

The concept of brand image has long been discussed since 1950; scholars have proposed various definitions of brand image. In general, brand image has been defined as the perception of consumer's mental picture and memory reflected by the brand (Keller, 1993; Cretu and Brodie, 2007; Kotler and Keller, 2012). Further, Martineau (1958) describes brand image as an integration of functional qualities and psychological attributes. Aaker (1991) elaborates brand image as an idea, feeling, and need of a brand. An understanding of the attributes, symbolic meanings, functional consequences and consumers' association with a product are also included in brand images (Padgett and Allen, 1997). Moreover, a clear brand image can help consumers identify and differentiate products of a firm from its competitors (Dobni and Zinkhan, 1990).

Consumer needs are an important factor influencing brand concept. Functional needs, symbolic needs, and experiential needs are considered the three components of consumer needs that can affect brand image (Park, Jaworski, and Maclnnis, 1986). Further, they defined brand images as the three concepts as follow:

1. Functional needs: Needs are defined as a brand image of helping consumers to solve consumption problems including the prevention of unexpected situations and the resolution of conflicts and contradictions.

2. Symbolic needs: Needs are to satisfy consumers' inner demands, such as enhancing self-worth, role definition and selfidentification. The symbolic benefit links to individuals and specific groups or self-image to the role of product performance.

3. Experiential needs: The consumers expect that products can provide sensory pleasant needs such as delight, fresh, and excitement on their perceptions.

Corporate brands are intangible assets of firms that are difficult to imitate by others (De Chernatony, 1999). Positive corporate image helps the firm increase their competitiveness (Porter and Claycomb, 1997); however, those benefits from a long-term marketing investment can be damaged severely by an incident of negative publicity in a relative short time (Cho, 2005; Henthorne and Henthorne, 1994; Zhu and Chang, 2013). How to rebuild brand images from negative publicity will be critical to any firm.

\subsection{Severity of Negative Publicity and Duration of CSR on Corporate Brand Image}


Studies have shown that corporate brand image can be affected by negative publicity (Zhu and Chang, 2013) Also, scholars have suggested that CSR can be an effective shelter or even a communication tool for companies to restore their brand image after negative publicity (Benoit, 1997; Klein and Dawar, 2004). Various studies have pointed out that the length of time invested in CSR influences and mitigates the impact of negative publicity (Vanhamme and Grobben, 2009). Thus, this study explores the impact of the severity of negative publicity and lengths of time devoted to CSR activities. Hypotheses are proposed as follows:

$\mathrm{H} 1_{0}$ : Consumer perceptions of a company brand image are lower for companies with high severity of negative publicity than for companies with low severity of negative publicity in Time 0 .

$\mathrm{H}_{2}$ : Consumer perceptions of a company brand image are lower for companies with a short history of CSR efforts than for companies with a long history of CSR efforts in Time 0 .

$\mathrm{H}_{3}$ : Consumer perceptions of company brand image are lower for a company with an interaction of a high severity of negative publicity and a short history of CSR efforts than for a company with an interaction of low severity of negative publicity and a long history of CSR efforts in Time 0.

Literature also suggested that duration (how long) of consumer reaction to negative publicity has varying effects on corporate brand images (Henthorne and Henthorne, 1994; de Matos and Veiga, 2005). Consumers' impression of negative publicity is likely to lessen or reduce over time according to impression information theory. Therefore, the hypotheses above will be reexamined a year after (Time 1 ) in order to compare the corporate brand image between Time 0 and Time 1:

$\mathrm{H}_{1}$ : Consumer perceptions of a company brand image are lower for companies with high severity of negative publicity than for companies with low severity of negative publicity and the outcome of brand image will be lower in Time 0 than in Time 1.

$\mathrm{H} 2{ }_{1}$ : Consumer perceptions of a company brand image are lower for companies with a short history of CSR efforts than for companies with a long history of CSR efforts and the outcome of brand image will be lower in Time 0 than in Time 1 .

$\mathrm{H}_{3}$ : Consumer perceptions of a company brand image are lower for company with an interaction of high severity of negative publicity and short history of CSR efforts than for a company with an interaction of low severity of negative publicity and long history of CSR efforts; and, the outcome of brand image will be lower in Time 0 than in Time1.

\section{DATA AND METHODOLOGY}

\subsection{Research Design}

This study takes a scenario exploratory (factorial-survey) design approach. Impression formation theory in social psychology provides a foundation to explain how consumers deal with negative market information. According to the theory, this research proposed that differences between severity of negative publicity and/or duration of CSR activities on brand image are framed in two time periods. The following is the research framework graphically.

Figure 1: Research Framework 


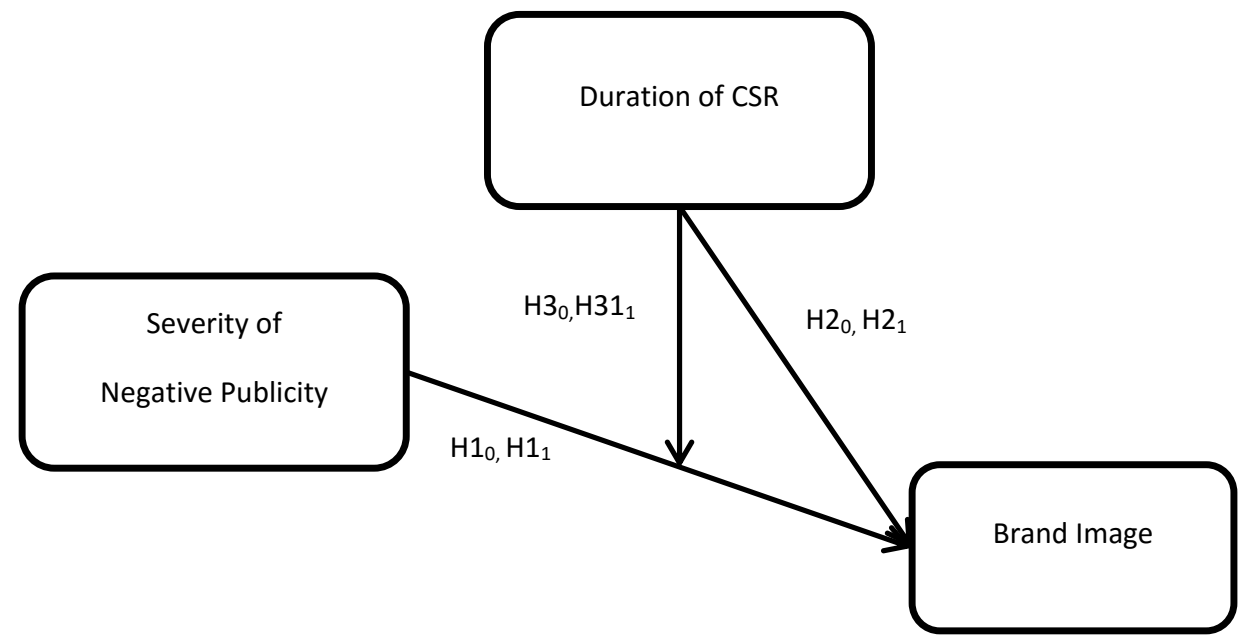

\subsection{Stimulus (Scenario) and Sample}

The restaurant chosen in this research was a well-known service provider. Its claim to fame was its assertion that its hotpot contained only natural ingredients. This hotpot restaurant is quite popular among students. A pretest of 40 students was conducted to make sure that the wordings of the survey fit the study.

A stimulus was designed in the survey to collect data. The students were shown the negative news about the restaurant to recreate the feelings of the moment. Online news stories and photos were collected and rearranged in relative sections (severity and CSR) of the questionnaires to simulate real situations.

A convenience sample was used. A total of 238 undergraduates and some graduate students in College of Business of Feng Chia university were invited to take the survey and extra points were offered to these students to both enhance their participations and pay attention to the survey. These respondents would be considered qualified as they knew the negative incident and had experience with the restaurant via a filter question. Further, the same students were again invited a year later in the same way. In the end, the valid responses were 225.

\subsection{Measurements and Analysis Approach}

Measurements included two statements of severity of the negative publicity and duration of CSR efforts. In Time 0 , a negative incident scenario using photos and news stories was introduced to respondents designed to recreate the moment to inducing respondents' feelings about the incidents in the past. Also, a statement was provided to recoup the theme of the negative incident. Duration of the CSR history used timeline to outline the history of the company's CSR actions (related to donations, treatments to employees, charitable giving to minority organizations... etc.) that the company has invested over the years. These two scenario statements applied 1-7 anchor scales to ask respondents' overall perceptions of how they feel the severity of the incident (high or low) and how do they think about the company has a long history in CSR or not (short or long). Then, the median of the anchor scales for both statements was used to determine high and low of the severity of negative publicity and long and short of the duration of CSR activities.

In addition, a multiple item scale was used to measure brand image adopted from Park, et.al (1986) and their three concept factors: functional, symbolic, and experiential. The items of brand image were measured by a five-point Likert-type scale ranging from "strongly disagree" (1) to "strongly agree" (5).

A year later, in Time1, the same questionnaire, including a description of the negative incident and the history of CSR and brand image was given to the same respondents to capture changes in perceptions and feelings toward the brand image a year after.

ANOVA and T-test were conducted to test the predictions set forth in hypotheses $\mathrm{H}_{1} \sim \mathrm{H} 3_{0}$ in time 0 and $\mathrm{H} 1_{1}, \mathrm{H} 2_{1}$, and $\mathrm{H} 3_{1}$ in Time1. In particular, T-test was used to test $\mathrm{H}_{1}, \mathrm{H} 2_{1}$ and $\mathrm{H} 3_{1}$ to compare multivariate sample means and changes between Time 0 and Time1, to determine if perceptions of brand image have changed over time. 


\section{FINDINGS AND DISCUSSIONS}

\subsection{Socio-Demographic and Descriptive Analyses}

A total of 225 valid questionnaires was collected. According to the data result, $39.65 \%$ were male respondents and $60.44 \%$ were female respondents. Most of the respondents were undergraduates about $90.22 \%$, the rest was graduate students. For descriptive analyses, perceptions of brand image for severity of negative publicity and CSR activities of the firm had a mean ranged from 3.38 to 2.95 and standard deviations ranged from 0.58 to 0.67 for both Time 0 and Time 1 (based on 5-points Likert scale). In addition, severity of the negative publicity had a mean of 5.48 and standard deviation of 1.23. As for the firm's history of CSR activities, its mean and standard deviation were 3.55 and 1.22, respectively. Both constructs were based on 1-7 anchor scale.

\subsection{Reliability and Validity}

Test-retest reliability was used to measure internal reliability and the value exceeded 0.7 , indicating internal consistency over time (Time 0 and time 1) for the construct of severity of negative publicity and duration of CSR activities. Cronbach $\alpha$ was used to test reliability for brand image of severity and CSR and these values were between 0.83 and 0.85 , showing a great internal consistency for the questionnaire in Time 0 and Time 1. Divergent validity was run for all constructs (Duration of CSR activities, severity of negative publicity and brand image for both severity and CSR). Correlations among these constructs were all lower than 0.56 , a value lower than .85, showing these constructs' dissimilarity (Campbell and Fiske, 1959) for Time 0 and Time 1. Further, composite reliability (CR) and average variance extracted (AVE) validity for brand image were conducted and values for CR and AVE were 0.81 and 0.66 , exceeding the minimum requirement threshold.

\subsection{Hypothesis Testing}

Mainly, one-way ANOVA was used to test hypotheses set in Time 0 (the negative incident incurred recently). The result showed that perceptions of brand image (of the hotpot restaurant) for low and high severity of the negative publicity were significant different ( $p$-value at .000) and that the low severity of negative publicity has a higher brand image than high severity (see table 1). $\mathrm{H} 1_{0}$ was supported.

Table 1: Results of Brand Image of Severity of the Negative Publicity in Time 0

\begin{tabular}{cccccccc}
\hline Brand Image & Sum of Squares & df & Mean Square & Mean & Standard Deviation & $\mathbf{F}$ & $\boldsymbol{p}$-Value \\
\hline Low Severity & 6.29 & 1 & 6.29 & 3.14 & 0.55 & 14.99 & .000 \\
\hline High Severity & 93.54 & 223 & 0.42 & 2.80 & 0.72 & & \\
\hline Total & 99.82 & 224 & & & & & \\
\hline
\end{tabular}

In addition, consumer perceptions of the brand image were significantly different and higher for the company with long history of CSR efforts than with a short history of CSR efforts in Time 0 . The result of the $p$-value was at 0.000 levels, indicating a highly significant difference (Table 2). As a result, $\mathrm{H}_{2}$ o was supported.

Table 2: Results of Brand Image of Duration of CSR Efforts in Time 0

\begin{tabular}{lccccccc}
\hline Brand Image & Sum of Squares & df & Mean Square & Mean & Standard Deviation & F & $p$-Value \\
\hline $\begin{array}{l}\text { Short Duration } \\
\text { of CSR Efforts }\end{array}$ & 5.41 & 1 & 5.41 & 3.17 & 0.62 & 15.93 & .000 \\
\hline $\begin{array}{l}\text { Long Duration } \\
\text { of CSR Efforts }\end{array}$ & 75.75 & 223 & 0.34 & 3.48 & 0.55 & \\
\hline Total & 81.16 & 224 & & & & \\
\hline
\end{tabular}

Further, consumer perceptions of the brand image were significantly different and lower at p-value of 0.000 level when an interaction of high severity of negative publicity and short history of CSR efforts than an interaction of low severity of negative publicity and long history of CSR efforts (Table 3). Thus, H30 was accepted.

Table 3: Brand Image with an Interaction between Severity and CSR in Time 0 


\begin{tabular}{ccccc}
\hline & Severity & CSR & Mean & $p(T<=t)$ one-tail \\
\hline \multirow{2}{*}{ Brand Image } & High & Short & 2.626 & .000 \\
\cline { 2 - 5 } & Low & Long & 3.276 & \\
\hline
\end{tabular}

To test hypotheses in Time 1 (a year after the incident), ANONA was first test to see differences in consumer perceptions of brand image for severity of negative publicity $\left(H 1_{1}\right)$, duration of CSR efforts $\left(H 2_{1}\right)$ and interaction of the two $\left(H 3_{1}\right)$, respectively. Then, a t-test was conducted further to see perception differences of brand images between Time 0 and Time 1. In Table 4, brand image was significantly different ( $p$-value at .001) for severity of negative publicity and lower when high severity of the incident was perceived (Table 4). T-test was followed up to compare brand image differences for high and low severity in Time 0 and Time 1. The findings confirmed $\mathrm{H}_{1}$ and the results indicated that perceptions of brand image for severity were significant different between Time 0 and Time 1 and have increased after a year despite the effect of severity levels (low or high) (Table 5).

Table 4: Results of Brand Image of Severity of the Negative Publicity in Time 1

\begin{tabular}{lccccccc}
\hline Brand Image & Sum of Squares & df & Mean Square & Mean & Standard Deviation & $\mathbf{F}$ & $\boldsymbol{p}$-Value \\
\hline Low Severity & 3.931 & 1 & 3.931 & 3.39 & 0.54 & 10.660 & .001 \\
\hline High Severity & 82.228 & 223 & 0.369 & 3.13 & 0.66 & & \\
\hline Total & 86.159 & 224 & & & & & \\
\hline
\end{tabular}

Table 5: Differences in Brand Image of High and Low Severity in Time 0 and Time 1

\begin{tabular}{lccccc}
\hline & \multicolumn{2}{c}{ High Severity } & & \multicolumn{2}{c}{ Low Severity } \\
\cline { 2 - 3 } \cline { 5 - 6 } & Brand Image Time 0 & Brand Image Time 1 & & Brand Image Time 0 & Brand Image Time 1 \\
\hline Mean & 2.80 & 3.13 & & 3.14 & 3.39 \\
\hline Variance & 0.51 & 0.43 & & 0.30 & 0.29 \\
\hline Observations & 125 & 125 & 100 & 100 \\
\hline df & 248 & & 198 & \\
\hline T Stat & 3.76 & & 3.32 & 0.0005 \\
\hline $\mathbf{P}(\mathbf{T}<=t)$ one-tail & 0.0001 & & & 0 & \\
\hline
\end{tabular}

For $\mathrm{H} 2_{1}$, perceptions of brand image for the duration of CSR efforts showed a significant difference at $p<002$ and brand image with a long duration of CSR efforts had a higher mean than short duration of CSR efforts (Table 6). Further, perceptions of brand image for the short duration of CSR efforts showed a significant difference ( $p$-value at .019) for Time 0 and Time 1 . However, perceptions of brand image for the long duration of CSR efforts had an insignificant difference ( $p$-value at .073) for Time 0 and time 1 (Table 7). Overall, hypothesis $\mathrm{H} 2_{1}$ was only partially supported.

Table 6: Results of Brand Image of Duration of CSR Efforts in Time 1

\begin{tabular}{lccccccc}
\hline Brand Image & Sum of Squares & df & Mean Square & Mean & Standard Deviation & F & p-Value \\
\hline $\begin{array}{l}\text { Short Duration } \\
\text { of CSR }\end{array}$ & 3.33 & 1 & 3.33 & 3.36 & 0.60 & 10.216 & .002 \\
\hline $\begin{array}{l}\text { Long Duration } \\
\text { of CSR }\end{array}$ & 72.62 & 223 & 0.33 & 3.60 & 0.55 & & \\
\hline Total & 75.95 & 224 & & & & & \\
\hline
\end{tabular}

Table 7: Differences in Brand Image of Short and Long CSR in Time 0 and Time 1 


\begin{tabular}{lccccc}
\hline & \multicolumn{3}{c}{ Short CSR } & & \multicolumn{2}{c}{ Long CSR } \\
\cline { 2 - 3 } \cline { 5 - 5 } & Brand Image Time 0 & Brand Image Time 1 & & Brand Image Time 0 & Brand Image Time 1 \\
\hline Mean & 3.18 & 3.35 & & 3.49 & 3.59 \\
\hline Variance & 0.39 & 0.36 & & 0.30 & 0.29 \\
\hline Observations & 106 & 106 & 119 & 119 \\
\hline df & 208 & & 234 & \\
\hline T-Stat & -2.08 & & -1.46 & \\
\hline $\mathbf{P}(\mathbf{T}<=$ t) one-tail & 0.019 & & 0.073 & \\
\hline
\end{tabular}

ANOVA and $T$-test were conducted to test $\mathrm{H}_{3}$ to see whether perceptions of brand image with an interaction of high severity of negative publicity and short history of CSR efforts or an interaction of low severity of negative publicity and long history of CSR efforts were significantly different in Time 0 and Time 1 . The results in Table 8 indicated that perceptions of brand image in both interactions of high severity with short duration of CSR efforts and low severity and long duration of CSR efforts were significant different at t-value of .002 and .02 , respectively. As a result, $\mathrm{H}_{1}$ was supported.

Table 8: Differences in Brand Image with Interactions of High Severity and Short CSR and Low Severity and Long CSR in Time 0 and Time 1

\begin{tabular}{lccccc}
\hline & \multicolumn{2}{c}{ High Severity \& Short CSR } & & \multicolumn{2}{c}{ Low Severity \& Long CSR } \\
\cline { 2 - 3 } \cline { 5 - 6 } & Brand Image Time 0 & Brand Image Time 1 & & Brand Image Time 0 & Brand Image Time 1 \\
\hline Mean & 2.63 & 3.03 & & 3.28 & 3.51 \\
\hline Variance & 0.60 & 0.47 & & 0.34 & 0.34 \\
\hline Observations & 61 & 61 & 55 & 55 \\
\hline df & 118 & & 108 & -2.088 \\
\hline T Stat & 3.02 & & 0.02 & \\
\hline $\mathbf{P}(\mathbf{T}<=\mathbf{t})$ one-tail & 0.002 & & & \\
\hline
\end{tabular}

\section{CONCLUSION}

\subsection{Academic Contributions}

In the field of negative publicity, little was known and rarely has investigated on how severity of negative publicity, duration of CSR efforts and their interactions impacted differently on consumer perceptions of brand image. In addition, a real scenario and cross times study have been scarce in the field. This research contributes to fill these gaps based on Impression Information theory. Results supported that severity of negative publicity made differences on consumer perceptions of corporate brand image in both Time 1 and Time 0 but duration of CSR efforts only made differences on corporate brand image only in Time 0 . The interactions of low severity of negative publicity and long CSR efforts and high severity of negative publicity and short CSR efforts were both significantly different in Time 0 and Time 1 . These findings enrich the knowledge of negative publicity.

In addition, the research answers an interesting question: Can a company leverage its past efforts in CSR to rectify its negative publicity resulted from irresponsible behaviors? Findings suggest that when the negative publicity incurred, corporate brand image dropped dramatically first and then was enhanced if consumers knew about the company's history of CSR efforts (in Time $0)$; however, consumers' impression on the negative incident has withered away so CSR made no significant difference on consumers' perception of corporate brand image a year after (in Time 1). This finding implies that as time goes by CSR has no halo effect to rectify corporate brand image in negative publicity. Consequently, these results lighten up a future direction of how CSR activities or communication can lessen the impact of negative publicity on firms.

\subsection{Practical Implications}

Findings supported that CSR can function or serve as a corporate brand image "safety net". Hence, CSR efforts can assist not only brand managers but also marketing strategy to restore brand image after negative publicity in service industry (in particular, 
restaurants). In addition, the results are especially salient for companies currently suffering from negative incidents, and provide an extra reason for companies who will or want to invest or to continue their investment in CSR as a competitive advantage.

In the short run when negative publicity just occurred, brand managers or marketing strategy in dealing with negative publicity should first communicate their CSR efforts right away in a way of showing their sincerity in trying to make things right and at the same time benefiting society at large. In particular, philanthropic donations to minority groups in need can increase positive brand image perception in a way that is easily seen by the public and therefore can promote longer lasting good impressions. In this way, consumer perceptions of corporate brand image will be regaining partially in spite of how severe was the negative publicity in a relative short time. Thus, engaging CSR actions can cultivate unique competitive advantages while offering the public substantial tangible and intangible social benefits.

However, CSR efforts may not manifest their halo effect in the long run. Findings also suggested that duration of CSR efforts made no significant differences in consumer perceptions of corporate brand image across times. Meaning that time itself might be a cure for restoring brand image. The implication for brand and strategic managers seem no need to do anything as consumers are very forgettable as the Impression Information theory makes sense that the impression of the negative incident is likely to fade away and might not be in consumer's memory after a year. This doesn't mean that brand and strategic managers have no need to rectify the negative incident; instead, this emphasizes the urgency of taking a swift action to deal with negative publicity in particular using CSR communications to rescue corporate brand image immediately. Continuing investments in CSR activities are needed because they can come to rescue in bad time. Overall, long-term efforts in CSR activities can enhance brand image no matter in good or bad time.

\subsection{Limitations and Future Research}

The research context was a restaurant which had a very specific negative publicity. In addition, convenient student sample was utilized even they were consumers to the restaurant. These could limit the generalizability of this study. Future studies should use random and different samples. Different contexts of negative publicity also need further investigations to support the findings in this study. In addition, other factors, not only concerning duration of CSR actions but the content of different types of CSR efforts may have more important implications than just time duration. Last but not the least, a study integrating two fields of negative publicity and CSR efforts into different industries and different products and services should be more comprehensible and may deliver new research models and be interesting to discover.

\section{REFERENCES}

Aaker, D. A. (1991). Managing brand equity. New York: Free Press.

Ahluwalia, R. Burnkrant, R. E., and Unnava, H. R. (2000). Consumer response to negative publicity: The moderating role of commitment. Journal of Marketing Research, 37(2), 203-214. DOI: 10.1509/jmkr.37.2.203.18734

Angelidis, J. P. and Ibrahim, N. A. (1993). Social demand and corporate strategy: A corporate social responsibility model. Review of Business, 15, 7-10.

Baghi, I., Rubaltelli, E. and Tedeschi, M. (2009). A strategy to communicate corporate social responsibility: Cause related marketing and its dark side. Corporate Social Responsibility and Environmental Management, 16, 15-26. DOI: 10.1002/csr.174

Bakar, A.S. A., and Ameer, R. (2011). Readability of corporate social responsibility communication in Malaysia. Corporate Social Responsibility and Environmental Management, 18, 50-60. DOI: 10.1002/csr.240

Becker-Olsen, K.L. and Hill, R. P. (2006). The impact of sponsor fit on brand equity: The case of nonprofit service providers. Journal of Service Research, 9, 73-83. DOI: 10.1177/1094670506289532

Benoit, W. L. (1997). Image repair discourse and crisis communication. Public Relations Review, 23(2), $177-186$.

Berens, G., Van Riel, C. B. M., and J. Van Rekom. (2007). The CSR-Quality Trade-Off: When can Corporate Social Responsibility and Corporate Ability Compensate Each Other? Journal of Business Ethics, 74, 233-52. DOI: 10.1007/s10551-006-9232-0

Brady, M. K., Cronin, J. J., Fox, G. L., and Roehm, M. L. (2008). Strategies to offset performance failures: The role of brand equity. Journal of Retailing, 84(2), 151-164. DOI: 10.1016/j.jretai.2008.04.002 
Carroll, A. B. (1979). A three-dimensional conceptual model of corporate performance. The Academy of Management Review, 4, 497-505. DOI: $10.2307 / 257850$

Carroll, A.B. (1991). The pyramid of corporate social responsibility: Toward the moral management of organizational stakeholders. Business Horizons, 34, 39-48. DOI: 10.1016/0007-6813(91)90005-G

Carroll, A. B. (1996). Ethics and Stakeholder Management. Southwestern Publishing: Cincinnati, OH.

Charter, M., Peattie, K., Ottman, J. and Polonsky, M. J. (2002). Marketing and Sustainability. Association with the Center for Sustainability Design. UK. Center for Business Relationships, Accountability, Sustainability and Society (BRASS). http://cfsd.org.uk/smart-know-net/smartknow-net.pdf

de Chernatony, L. (1999). Brand management through narrowing the gap between brand identity and brand reputation. Journal of Marketing Management, 15(1-3), 157-179. DOI: 10.1362/026725799784870432

Cho, Y. Y. (2005). The effect of negative publicity on consumers' brand evaluation: the moderating role of corporate advertising. University of Missouri-Columbia, Thesis. Retrieved from ProQuest.

Chung, L. (2013). Concerns over food safety build in Taiwan after scandals: Incidents involving how edible oil companies label their products have damaged trust in entire industry trying to rebuild its reputation. https://www.scmp.com/news/china/article/1348274/concerns-over-foodsafety-build-taiwan-after-scandals

Commission of the European Communities. (2001). Green paper 'Promoting a European framework for corporate social responsibility'. Brussels.

Cretu, A. E., and Brodie, R. J. (2007). The influence of brand image and company reputation where manufacturers market to small firms: A customer value perspective. Industrial Marketing Management, 36 (2), 230-40. DOI: 10.1016/j.indmarman.2005.08.013

Dahlen, M., and Lange, F. (2006). A disaster is contagious: How a brand in crisis affects other brands. Journal of Advertising Research, 46(4), 388397. DOI: $10.2501 /$ S0021849906060417

Dobni, D., and Zinkhan, G. M. (1990). In search of brand image: A foundation analysis, in NA - Advances in Consumer Research Volume 17, eds. Marvin E. Goldberg, Gerald Gorn, and Richard W. Pollay, Provo, UT : Association for Consumer Research, Pages: 110-119. http://acrwebsite.org/volumes/7005/volumes/v17/NA-17

Dyllick, T., Hockerts, K. (2002). Beyond the business case for corporate sustainability. Business Strategy and the Environment, 11, $130-141$. DOI:10.1002/bse.323

Elkington, J. (1994). Towards the sustainable corporation: win-win-win business strategies for sustainable development. California Management Review, 36, 90-100. DOI: 10.2307/41165746

Enderle, G. and Tavis, A. L. (1998). A balanced concept of the firm and the measurement of its long-term planning and performance. Journal of Business Ethics, 17, 1129-1143. DOI: 10.1023/A:1005746212024

First, I., and Khetriwal, D. S. (2010). Exploring the relationship between environmental orientation and brand value: Is there fire or only smoke? Business Strategy and the Environment, 19, 90-103. DOI: 10.1002/bse.619

Fiske, S. T. (1980). Attention and weight in person perception: the impact of negative and extreme behavior. Journal of Personality and Social Psychology, 38(6), 889-906. DOI: 10.1037/0022-3514.38.6.889

Griffin, M., Babin, B. J., \& Attaway, J. S. (1991). An empirical investigation of the impact of negative public publicity on consumer attitudes and intentions. Advances in Consumer Research, 18(1), 334-341. http://acrwebsite.org/volumes/7182/volumes/v18/NA-18

Hart, S. (1995). A natural resource-based view of the firm. Academy of Management Review, 20(4), 986-1014. DOI: 10.2307/258963

Henard, D. H. (2002). Negative publicity: What companies need to know about public relations. Public Relations Quarterly, 47(4), 8-12.

Henthorne, B. H., and Henthorne, T. L. (1994). The tarnished image: Anticipating and minimizing the impact of negative publicity in health services organizations. Journal of Consumer Marketing, 11(3), 44-54.

Hsu, S. (2014). FDA traces banned dye back to Tainan firm. Taipei Times.

http://www.taipeitimes.com/News/front/archives/2014/12/17/2003606920 
Joireman, J., Smith, D, Liu, R. L., and Arthurs, J. (2015). It's all good: Corporate social responsibility reduces negative and promotes positive responses to service failures among value-aligned customers. Journal of Public Policy \& Marketing, 34(1), 32-49. DOI: 10.1509/jppm.13.065

Keller, K. L. (1993). Conceptualizing, measuring, and managing customer-based brand equity. Journal of Marketing, 57(1), 1-22. DOI: $10.2307 / 1252054$

Klein, J., and Dawar, N. (2004). Corporate social responsibility and consumers' attributions and brand evaluations in a product-harm crisis. International Journal of Research in Marketing, 21, 203-217. DOI: 10.1016/j.ijresmar.2003.12.003

Kotler, P. (2008). Marketing management (13th ed.), Upper Saddle River, NJ: Prentice-Hall.

Kotler, P., \& Keller, K. L. (2012). Marketing management (14 ${ }^{\text {th }}$ global ed.), Upper Saddle River, NJ: Prentice-Hall.

Lachowetz, T., Clark, J. M., Irwin, R. \& Cornwell, T. B. (2002). Cause-related sponsorship: A survey of consumer/spectator beliefs, attitudes, behavioral intentions, and corporate image impressions. American Marketing Association Conference Proceedings, 13, 14-20.

Lerner, D. L. and Fryxell, E. G. (1988). An empirical study of the predictors of corporate social performance: a multi-dimensional analysis. Journal of Business Ethics, 7, 951-959.

Li, Y. (2015). The severity of negative events in enterprises affects consumers' brand attitude. Social Behavior and Personality, 43(9), $1533-1546$. DOI: 10.2224/sbp.2015.43.9.1533

van Marrewijk, M. (2003). Concepts and definitions of CSR and corporate sustainability: Between agency and communion. Journal of Business Ethics, 44, 95-105. DOI: /10.1023/A:1023331212247

Martineau, P. (1958). The personality of the retail store. Harvard Business Review, 36(1), 47-55

de Matos, C. A. and Veiga, R. T. (2005). How to deal with negative publicity: the importance of consumer involvement. Brazilian Administration Review, 2(1), 57-72. DOI: 10.1590/S1415-65552005000600005

Mohr, L. A., Webb, D. J., and Harris, K.E. (2001). Do consumers expect companies to be socially responsible? The impact of corporate social responsibility on buying behavior. Journal of Consumer Affairs, 35(1), 45-72. DOI: 10.1111/j.1745-6606.2001.tb00102.x

Nan, X., and Heo, K. (2007). Consumer response to corporate social responsibility (CSR) initiatives: Examining the Role of Brand-Cause Fit in Cause-Related Marketing. Journal of Advertising, 36, 63-74. DOI: 10.2753/JOA0091-3367360204

Padgett, D., and Allen, D. (1997). Communicating experiences: A narrative approach to creating service brand image. Journal of Advertising, 26(4), 49-62. DOI: 10.1080/00913367.1997.10673535

Park, C. W., Jaworski, B. J., and Maclnnis, D. J. (1986). Strategic brand concept-image management. Journal of Marketing, 50, 135-145. DOI: $10.2307 / 1251291$

Perrini, F., Castaldo, S., Misani, N., and Tencati, A. (2010). The impact of corporate social responsibility associations on trust in organic products marketed by mainstream retailers: A study of Italian consumers. Business Strategy and the Environment, 19, 512-526. DOI: 10.1002/bse.660

Polonsky, M.J. and Speed, R. (2001). Linking sponsorship and cause related marketing: complementary and conflicts. European Journal of Marketing, 35, 1361-1389. DOI: 10.1108/EUM0000000006484

Porter, M. E., and Kramer, M. R. (2006). Strategy \& Society: The link between competitive advantage and corporate social responsibility. Harvard Business Review, 84, 78-92.

Porter, M. E. and Kramer, M. R. (2011). Creating share value: How to reinvest capitalism and unleash a wave of innovation and growth. Harvard Business Review, 89, 62-77.

Porter, S.S., and Claycomb, C. (1997). The influence of brand recognition on retail store image. Journal of Product and Brand Management, 6(6), 373-385. DOI: 10.1108/10610429710190414

Pullig, C., Netemeyer, R. G., and Biswas, A. (2006). Attitude basis, certainty, and challenge alignment: A case of negative brand publicity. Journal of the Academy of Marketing Science, 34(4), 528-542. DOI: 10.1177/0092070306287128

Reidenback, E. R., Festervand, T. A., and Macwilliam, M. (1987). Effective corporate response to negative publicity. Business, Oct.-Dec., 8-17.

Rodriguez, M. A., Ricart, J.E., and Sanchez, P. (2002). Sustainable development and sustainability of competitive advantage: a dynamic and sustainable view of the firm. Creativity Innovation Management, 11, 135-146. DOI: 10.1111/1467-8691.00246 
Schoefer, K., and Ennew, C. (2005). The impact of perceived justice on consumers' emotional responses to service complaint experiences. Journal of Services Marketing, 19(5), 261-270. DOI: 10.1108/08876040510609880

Sen, S., and Bhattacharya, C. B. (2001). Does doing good always lead to doing better? consumer reactions to corporate social responsibility. Journal of Marketing Research, 38, 225-243.

Sherell D. L., and Reidenbach, E. R. (1986). A consumer responses framework for negative publicity: Suggestions for responses strategies. Akron Business and Economic Review, 17(2), 37-44.

Smallbone, T. (2004). Can 'market transformation' lead to 'sustainable business'? A critical appraisal of the UK's strategy for sustainable business. Business Strategy and the Environment, 13, 96-106. DOI: 10.1002/bse.397

Vanhamme, J., and Grobben, B. (2009). Too good to be true! The effectiveness of CSR history in countering negative publicity. Journal of Business Ethics, 85, 273-283. DOI: 10.1007/s10551-008-9731-2

Webb, D. J. and Mohr, L. A. (1998). A typology of consumer responses to cause-related marketing: From skeptics to socially concerned. Journal of Public Policy and Marketing, 17, 226-238. DOI: 10.1177/074391569801700207

Wu, S., and Kao, Y. L. (2013). Food safety problems worry 80\% of Taiwan's public: poll. http://focustaiwan.tw/news/asoc/201311050044.aspx

Xie, Y. and Peng, S. (2010). The effects of two kinds of corporate publicity on customer-brand relationship. Frontier Business Research China, 4(1), 73-100. DOI: 10.1007/s11782-010-0004-4

Zhu, D., and Chang, Y. (2013). Negative publicity effect of the business founder's unethical behavior on corporate image: Evidence from China. Journal of Business Ethics, 117, 111-121. DOI: 10.1007/s10551-012-1512-2 